\title{
Settlement behavior in shore crabs Carcinus maenas: why do postlarvae emigrate from nursery habitats?
}

\author{
Per-Olav Moksnes*, Ola Hedvall, Torsten Reinwald
}

Department of Marine Ecology, Göteborg University, Kristineberg Marine Research Station, 45034 Fiskebäckskil, Sweden

\begin{abstract}
In contrast to general settlement models of invertebrate larvae, recent Swedish studies of settlement of the shore crab Carcinus maenas indicate that many postlarvae close to metamorphosis emigrate from their preferred settlement habitats. In the present study, we assessed physical and biological factors affecting shore crab settlement and emigration from nursery habitats, and explored possible ultimate factors in this behavior. Postlarval abundance in the field was not affected by the tidal phase, but varied significantly according to the light conditions. Settlement densities on artificial substrates were significantly higher during the day compared to at night. In contrast, densities of planktonic postlarvae were highest at night. This result suggests that the postlarvae cling to shallow benthic habitats during the day and swim in the plankton at night. Mesocosm experiments demonstrated that most postlarvae remained in the benthos during the day, even in suboptimal habitats, but that a large proportion (on average $58 \%$ ) actively emigrated at dusk, irrespective of settlement conditions. Emigration rates were significantly higher and metamorphosis rates lower in open sand compared to mussel habitats, whereas food levels and settlement densities had only small effects on the settlement process. Emigrated postlarvae were at a significantly earlier developmental stage and metamorphosed on average $1 \mathrm{~d}$ later than the megalopae that remained in the benthic habitat. Postlarvae $>2 \mathrm{~d}$ from metamorphosis emigrated even from optimal settlement conditions. These results suggest that settlement in shore crabs is not an irreversible process once a late-stage postlarva has found a settlement habitat, but involves 2 separate behavioral components: (1) the selection of a benthic habitat during the day, which is mainly affected by the availability of refuges from predation; and (2) the choice to stay or emigrate the following night, where emigration is induced by a decrease in light and determined mainly by the development stage of the postlarvae. We propose a conceptual model of settlement in the shore crab where the dynamic behavior of the postlarvae is an adaptation to diel differences in predation risk between the settlement habitat and the plankton.
\end{abstract}

KEY WORDS: Settlement cues · Swimming behavior $\cdot$ Habitat selection $\cdot$ Migration · Metamorphosis · Planktonic mortality $\cdot$ European green crab

\section{INTRODUCTION}

Most benthic macro invertebrates produce pelagic larvae that disperse for days or months in the plankton before settling into a benthic habitat. The early idea that planktonic larvae were passively dispersed and settled at random when larval development was completed (Nelson 1928, Colman 1933) was rejected once it became clear that the development rate and the behavior of many larvae were affected by specific environmental stimuli (Crisp 1974). Many larvae migrate vertically in the water column on both ontogenetic and diel schedules in response to endogenous rhythms and/or specific physical and biological cues. This swimming behavior may affect the large-scale horizontal transportation of larvae (see Shanks 1995, Forward \& Tankersley 2001 for review) and help in the selection of settlement habitats that will increase the survival of the benthic stages (see Meadows \& Campbell 1972, Crisp 1974, Pawlik 1992 for review). The 
larvae of a diverse range of marine organisms behave very similarly as settlement approaches: they migrate towards the bottom, often in response to a specific combination of environmental stimuli, and 'touch down' periodically on different habitats to examine the surface. The presence or lack of specific chemical and/or physical cues in the habitat will either cause the larvae to emigrate back into the water column, to be transported to another area, or to settle and metamorphose into the benthic stage (Meadows \& Campbell 1972, Crisp 1974, Pawlik 1992).

Because settling larvae are very small and cryptic, settlement behavior is difficult to study under natural conditions. Most of our understanding of this is based on laboratory studies of sessile and infaunal organisms; much less is known about mobile invertebrates, which are harder to study, particularly in the field (Hunt \& Scheibling 1997). However, an increasing number of experimental studies on marine decapods suggest that the behavior of settling larvae plays an important role in the distribution and survival of their recruits. Active habitat selection at settlement has been demonstrated for several decapod species in both the laboratory (Botero \& Atema 1982, Herrnkind \& Butler 1986, Fernandez et al. 1993, Liu \& Loneragan 1997, Hedvall et al. 1998, Stevens \& Kittka 1998) and in the field (Eggleston \& Armstrong 1995, Moksnes 2002). These species select structurally complex habitats at settlement, which provide refuge from predation for the postlarvae and young benthic stages (Barshaw \& Able 1990, Smith \& Herrnkind 1992, Fernandez et al. 1993, Moksnes et al. 1998).

The shore crab Carcinus maenas (L.) is one of the most studied decapod species, and intensive work in the last decade has dramatically increased our understanding of its larval behavior during the dispersal phase and at settlement. The larval phase of the shore crab includes 4 pelagic zoea stages and a megalopal (postlarval) stage that settles and metamorphoses into the first benthic crab stage. The duration of the megalopal stage varies from 9 to $16 \mathrm{~d}$ depending on temperature (Mohamedeen \& Hartnoll 1989). Recent studies of the shore crab larvae from tidal areas suggest that vertical migration behavior in phase with local tides may control both the dispersal of zoea larvae from the coast (Zeng \& Naylor 1996a, Queiroga et al. 1997, Duchêne \& Queiroga 2001) and the migration of the megalopal stage back to nursery areas (Queiroga et al. 1994, Zeng \& Naylor 1996b, Queiroga 1998). Little is known about vertical migration behavior in crab larvae from systems where tidal currents do not play a significant role in the water movements, such as the microtidal area along the Swedish west coast.

In western Sweden, shore crab megalopae settle between June and October (Moksnes 1999), and young juvenile crabs are found mainly in shallow $(<1 \mathrm{~m})$, soft sediment bays (Pihl 1986). Within these nursery areas, settlers (megalopae and first-instar crabs) are concentrated at high densities in several structurally complex microhabitats, primarily in blue mussel beds Mytilus edulis (L.) and shell debris, and also in eelgrass beds and in filamentous macroalgae. However, lower densities $(40 \times)$ are found in adjacent open sand or mud (Moksnes 2002). Recent laboratory flume and field cage experiments have demonstrated that megalopae avoid open sand habitats and actively select mussel shell, eelgrass or algal habitats at settlement (Hedvall et al. 1998, Moksnes 2002). Decreased mortality in the selected habitats suggests that this behavior is an adaptation to reduce predation (Moksnes et al. 1998). Young juvenile crabs are agonistic to each other, and density-dependent growth, emigration and cannibalism have been demonstrated at naturally occurring densities (Moksnes 1999). However, it is not known if or how settlement densities affect the behavior of settling megalopae. It is also unclear whether food availability affects habitat selection at settlement.

Recent field studies of larval behavior and settlement in Swedish shore crabs suggest that many postlarvae in a late development stage emigrate from their preferred settlement habitats. Experiments using artificial settlement collectors and larval migration traps indicated that most postlarvae were transient in nursery areas and emigrated after clinging to the habitats for about $12 \mathrm{~h}$, although they were only 2 to $3 \mathrm{~d}$ from metamorphosis (Moksnes \& Wennhage 2001, Moksnes 2002). These puzzling results are not in accordance with general settlement models of invertebrate larvae. They contrast with the 'settle and stay hypothesis', which states that planktonic larvae of seagrass associated fish and crustaceans (including portunid crabs) will settle into the first seagrass habitat they encounter, irrespective of quality, because mortality in the plankton is very high (Bell \& Westoby 1986). They are also inconsistent with a settlement model in American lobster Homarus americanus Milne-Edwards, which suggests that postlarvae will permanently settle when the preferred habitat is encountered, irrespective of development state (Barshaw \& Rich 1997).

In this study, a series of short field and laboratory experiments were performed to assess physical and biological factors affecting settlement behavior in shore crabs. The major objectives were: (1) to test if tidal phase and light period affect the swimming and settlement behavior of megalopae; (2) to assess if the refuge and food quality of the habitat, settlement densities and the development stage of the postlarvae affect the emigration rate from the habitat and (3) to explore possible ultimate factors in this apparently non-adaptive emigration behavior. 


\section{MATERIALS AND METHODS}

Field experiments: effect of tidal phase, light period and water depth. To assess the swimming and settlement behavior in shore crabs, 2 short field experiments were conducted in a shallow bay next to Kristineberg Marine Research Station, located in the Gullmarsfjord on the Swedish west coast $\left(56^{\circ} 15^{`} \mathrm{~N}, 11^{\circ} 35^{`} \mathrm{E}_{i}\right.$ Fig. 1). In this area, the Baltic current creates a pycnocline that is generally found at 15 to $20 \mathrm{~m}$ depth with higher salinity water underneath: summer surface salinity and temperature normally range from 15 to 30 , and 15 to $20^{\circ} \mathrm{C}$, respectively (Svansson 1984). Tides in the area are semidiurnal with small amplitude, normally $<0.3 \mathrm{~m}$ (Moksnes \& Wennhage 2001). The water exchange to shallow bays in the Gullmarsfjord is driven mainly by density differences (baroclinic circulation), wind, and large-scale currents along shore, whereas tides are thought to play a negligible role (Andersson \& Rahm 1985, Söderkvist 1997).

A 3 d field experiment was conducted September 6 to 9,1997 to assess how abundance of shore crab settlers on artificial settlement collectors varied in relation to tidal phase, light period, and water depth. We used standardized cylindrical collectors (van Montfrans et al. 1995) consisting of 'hogs-hair' air-conditioning filter material wrapped around a floating PVC pipe. A recent evaluation of this technique for shore crabs

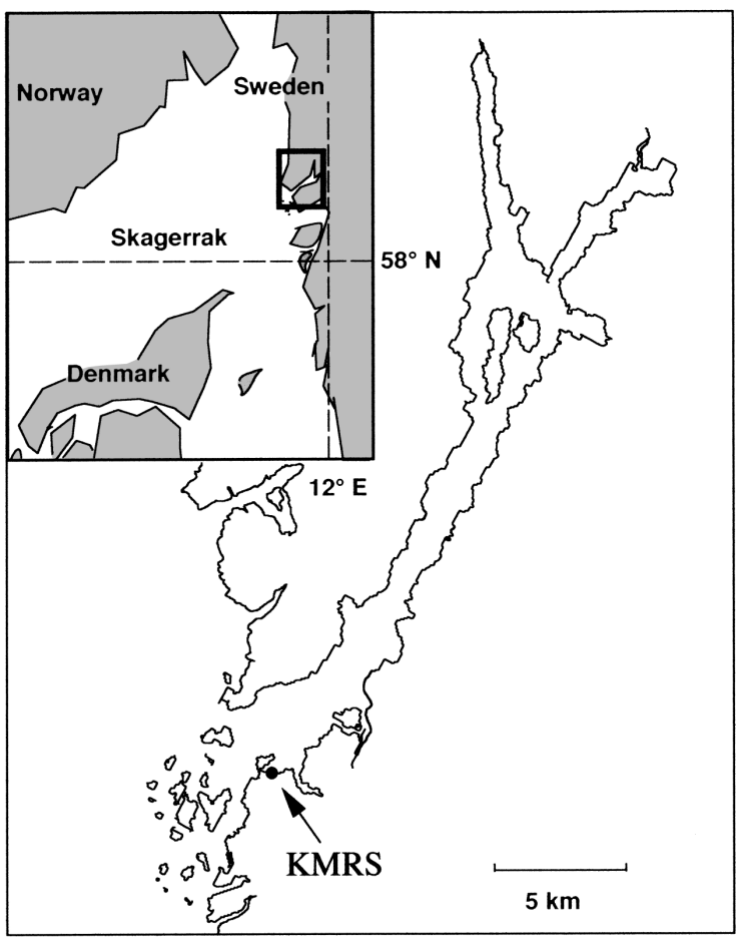

Fig. 1. Location of the Gullmarsfjord (western Sweden) and the shallow bay next to Kristineberg Marine Research Station (KMRS) where the field experiments were carried out demonstrated that megalopal abundance on collectors correlates both to water column abundance of postlarvae, and to settlement densities in blue mussel beds (Moksnes \& Wennhage 2001). Replicate collectors were randomly placed along the $10 \mathrm{~m}$ depth curve at the opening of the shallow bay, either floating at the water surface or placed $1 \mathrm{~m}$ above the bottom $(\mathrm{n}=3)$. The collectors were immersed for approximately $6.15 \mathrm{~h}$, following the local semidiurnal tides, and collected at expected slack tide between tidal changes. This resulted in 4 distinct tidal phase/light periods being sampled each day: (1) morning ebb (before to after dawn), (2) day flood, (3) evening ebb (before to after dusk), (4) night flood. At this latitude dawn occurred approximately from 06:30 to $08: 00 \mathrm{~h}$ and dusk from 18:30 to 20:00 $\mathrm{h}$ during the experimental period. The collectors were retrieved by boat, carefully placed in 301 buckets, soaked for a minimum of $30 \mathrm{~min}$ in fresh water before being rinsed into a $750 \mu \mathrm{m}$ sieve, after which postlarvae and first-instar shore crabs were identified and enumerated alive.

The experiment was repeated September 14 to 16 in the same bay when the same tidal/light phase combination was sampled. In this experiment we also performed plankton net tows at the opening of the bay to assess day-night differences of water column abundance of megalopae, since an effect of light period was detected in the first experiment. Plankton net tows were performed with a circular plankton net $(250 \mu \mathrm{m}$ mesh; $0.5 \mathrm{~m}^{2}$ opening) fitted with a mechanical flowmeter, and towed from a small boat at the surface across the opening of the bay (approx. $200 \mathrm{~m}, 6$ to $8 \mathrm{~min}$ duration, sampling approx. $100 \mathrm{~m}^{3}$ of water) above the $10 \mathrm{~m}$ depth curve. Day and nighttime tows were carried out between 14:00 and 16:00 h, and 01:00 and 03:00 h, respectively. Tidal amplitude, water temperature and salinity, and light intensity (PAR) were constantly measured at Kristineberg Marine Research Station next to the bay over the course of both experiments.

In each experiment, the number of settlers per collector was used as the dependent variable in a 3 -factor, mixed ANOVA model with tidal/light phase (4 levels, fixed factor), depth (surface and bottom, fixed factor) and day (Day 1 to 3, random factor) as independent variables. Day-night differences in water column abundance of megalopae from the plankton tows were assessed in a 2-factor ANOVA model with light phase (day and night) and day as independent variables, and number of megalopae per $100 \mathrm{~m}^{3}$ of water as the dependent variable. Residuals were tested for temporal autocorrelation using a test of serial independence (Sokal \& Rohlf 1995). All data were tested for homoscedasticity with Cochran's C-test (Sokal \& Rohlf 1981) and $\log (x+1)$-transformed to meet the assumption of homogenous variance. A posteriori multiple compar- 
isons were carried out with the Student-Newman Keuls (SNK) procedure.

Laboratory experiments: effect of habitat quality and conspecific densities. The field experiments indicated little effect of tidal phase, but a strong effect of the light period on megalopal swimming and settlement behavior. To further investigate the effect of light, and also to assess how biological factors affected settlement and emigration of shore crab megalopae from natural habitats, 2 laboratory experiments were conducted during July and August 1998 at Kristineberg Marine Research Station.

General laboratory experimental procedures: Eight cylindrical flow-through (approx. $31 \mathrm{~min}^{-1}$ ) mesocosms $\left(0.19 \mathrm{~m}^{2}\right)$ with approximately $40 \mathrm{~cm}$ water depth above the sand substratum (total volume $=80 \mathrm{l}$ ) were used in both experiments. Water entered along the tank wall and left at the surface in the center through a pipe, creating a continuous circular current in the tank (Fig. 2). Any megalopae swimming randomly in the water column would be swept out through the exit pipe within $30 \mathrm{~min}$ and collected in a cup equipped with $750 \mu \mathrm{m}$ mesh placed underneath each tank in a water-channel bath (Fig. 2). This experimental setup was thought to approximate natural conditions where megalopae that let go of a substrate and start swimming in the shallow bays will be quickly transported away from the habitat and the nursery area. Filtered $(750 \mu \mathrm{m})$ water was pumped in from a shallow bay next to the lab at $1 \mathrm{~m}$ depth, and showed natural fluctuations in temperature and salinity. Three sources of light were used to provide $15 \mathrm{~h}$ daylight, $6 \mathrm{~h}$ darkness and $1.5 \mathrm{~h}$ of dusk (21:00 to $22: 30 \mathrm{~h})$ and dawn (04:30 to 06:00 h), respectively, approximating natural light conditions during the summer in Sweden. Shore crab megalopae were collected in the shallow bay next to the station using migration traps (see Moksnes \& Wennhage 2001 for details) and artificial settlement collectors. At the start

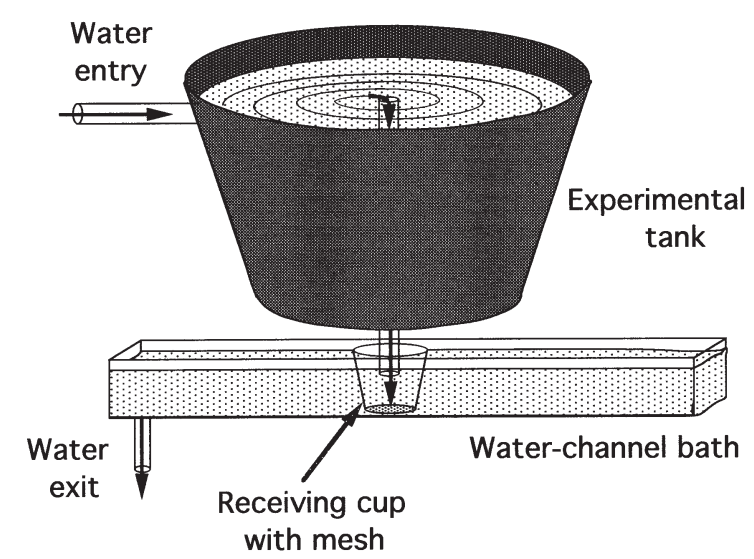

Fig. 2. Experimental setup for the laboratory experiments showing a mesocosm tank and the water-channel bath with the cup that collected emigrated megalopae of each trial, the water supply was stopped and megalopae were carefully introduced to the surface from 0.51 cups (up to 20 larvae cup ${ }^{-1}$ ) until the desired larval density was reached. At lower megalopal densities, cups with water only were also used to standardize the disturbance in all treatments. The megalopae were allowed to adapt in the tanks for $30 \mathrm{~min}$ before the water supply was started, which denoted the beginning of a trial. All trials were initiated during daylight hours but at different times, to decouple the effect of light period from the time of introduction. The cups under the tanks were checked 30 min after starting, and before and after dusk and dawn in both experiments. Emigrated megalopae were continuously transferred to 101 buckets (1 for each experimental tank) that were standing in water-channel baths to stabilize temperature. Upon termination of each trial, the water in each tank was sieved through $750 \mu \mathrm{m}$ mesh (see Moksnes et al. 1998 for recovery methods), and all animals were enumerated live and checked for metamorphosis. The number of missing megalopae was assumed to reflect cannibalism since losses due to handling during recovery were very low (0 to $3 \%$ ).

To assess if the development stage differed between the megalopae that remained in the tanks and the ones that emigrated, and if the experimental treatments affected the development rate, 10 megalopae (when possible) from each tank and bucket were transferred to separate 0.51 cups and monitored for metamorphosis rate after each experimental trial. On a daily basis they were fed Artemia sp. nauplii (only in Expt 2), the water was changed in the cups and all first-instar crabs were enumerated and removed, and average time to metamorphosis (TTM) was calculated for each cup. Data from either the emigrated or the remaining megalopae from each tank were randomly chosen for the statistical analysis to meet the assumption of independence between samples.

Expt 1: effect of habitat and food: The effect of habitat and food supply on megalopal settlement and emigration was assessed by using 2 different habitats (blue mussels and bare sand) in combination with 2 levels of food (excess of food and no additional food). The blue mussel habitat consisted of sand and 20 live adult mussels in a tightly packed bed, located in the middle of the tank. Blue mussels were chosen because shore crab megalopae actively select this habitat at settlement (Hedvall et al. 1998, Moksnes 2002) and because mussels provide a significant refuge from predation (Moksnes et al. 1998). The excess of food treatment consisted of half of a finely chopped blue mussel (shell and digestive gland removed) and approximately 30000 freezekilled Artemia sp. nauplii (these food sources are readily eaten by megalopae and first-instar crabs). Two replicates of each of the 4 habitat and food combina- 
tions were assessed in 3 different trials $(n=6)$, using megalopal densities (of 60, 40 and 50 megalopae tank ${ }^{-1}$ and starting times 17:00, 15:00 and 21:00 h, respectively. The trials were run for approximately $40 \mathrm{~h}$. Proportional emigration rate (per $40 \mathrm{~h}$ ) of megalopae (no. found emigrated/total no. recovered), proportion of megalopae that emigrated before the first dusk (no. of megalopae emigrating before dusk/total no. of megalopae emigrating), proportional loss rate ([no. introduced - no. recovered]/no. introduced; per $40 \mathrm{~h}$ ), and proportional metamorphosis rate (no. of first-instar crabs/total no. of settlers recovered from buckets and tanks; per $40 \mathrm{~h}$ ) were used as the dependent variables in 4 separate 3 -factor ANOVA models with habitat, food and trial as independent variables. The proportion that emigrated before dusk was analyzed to test if megalopae emigrate earlier from poor-quality habitats.

TTM was measured in both emigrated (from buckets) and non-emigrated megalopae (from tanks) that remained at the end of the experiment in the last 2 trials and analyzed in a 3-factor ANOVA model with settlement behavior (emigrated or stayed), habitat and food as independent variables, and the trials as replicates. Average no. of days to metamorphosis per cup was used as the dependent variable.

Because few megalopae remained in the tanks after the experiment (on average 4.3 megalopae), lower densities of megalopae were used in the cups from the tanks compared to the buckets (10 megalopae at all times). A subsequent analysis of cannibalism in the cups showed significantly higher rates among the megalopae from the buckets (19\% mortality) compared to megalopae from the tanks ( $9 \%$ mortality) in both trials (ANOVA, $F=5.0$, $\mathrm{df}=1,27, \mathrm{p}<0.05)$. Since we were concerned that the differences in densities used in the TTM experiment and cannibalism could affect the estimates of TTM (cannibalism likely occurs on newly metamorphosed individuals), a complementary experiment was performed to assess the effect of megalopal densities and food on metamorphosis rates and cannibalism. Seven densities of megalopae $\left(1,2,4,8,16,32\right.$ and 64 megalopae cup $\left.{ }^{-1}\right)$ were placed in replicated cups and assessed for TTM as described earlier, where half were fed Artemia sp. nauplii daily and the other half received no food $(n=4)$. Time to metamorphosis and loss rates were analyzed in 2 separate 2-factor ANOVA (mixed) models with megalopal density (random factor) and food treatment as independent variables.

Expt 2: effect of settlement density: The effect of megalopal density on settlement and emigration rates was tested using blue mussels as habitat (12 live adult mussels) and 4 densities of megalopae $(12,36,108$ and 324 megalopae $\operatorname{tank}^{-1}$; equivalent to approx. 63 to 1705 megalopae $\mathrm{m}^{-2}$ ), selected to reflect natural density ranges from low to very high settlement during recruit- ment (Moksnes 2002). All megalopae were provided with an excess of food (blue mussel and Artemia sp.). Three trials were assessed, which started at different times $(16: 00,19: 00$ and 21:00 h), with 2 replicates of each density treatment at each trial. These trials were stopped in the morning after the first night, since Expt 1 demonstrated very little emigration after the first night.

Proportional emigration rate (per $15 \mathrm{~h}$ ), proportion of megalopae that emigrated before the first dusk, proportional loss rate (per $15 \mathrm{~h}$ ), and proportional metamorphosis rate (per $15 \mathrm{~h}$ ) were used as dependent variables in 4 separate 2-factor (mixed) ANOVA models with density (random) and trial as independent variables. TTM in remaining megalopae from tanks and buckets was analyzed in a 2-factor (mixed) ANOVA model with settlement behavior and density (random) as independent variables. Since high cannibalism rates were found in the cups in Expt 1, Artemia sp. nauplii were given as food in the TTM experiment to reduce this potential artifact.

\section{RESULTS}

\section{Field experiments: effect of tidal phase, light period and water depth}

In the first experiment, abundance of shore crab settlers on artificial collectors differed significantly between tidal-light phases, but the temporal pattern was only found on surface collectors causing a significant tidal-light phase $\times$ depth interaction effect (Fig. 3, Table 1). On surface collectors, densities were significantly higher after the morning ebb and the day flood (average 65.9 and 71.2 settlers collector ${ }^{-1}$, respectively) compared to the evening ebb and night flood samples (1.3 and 1.7 settlers collector ${ }^{-1}$, respectively) on all days. On bottom collectors, densities were low at all times (on average 0.4 to 0.7 settlers collector ${ }^{-1}$ ) and no significant differences were detected between treatments (SNKtest, $\mathrm{p}>0.05)$. Densities of settlers were significantly higher on surface collectors compared to bottom collectors in the morning ebb and day flood samples only. The abundance of shore crab settlers varied significantly between days on surface collectors but not on bottom collectors causing a significant depth $\times$ day interaction effect (Table 1). The effect of the tidal-light phase appears to be an effect of light only, since densities from ebb- and flood-tide samples were very similar on all days (average 18.4 and 17.2 settlers collector $^{-1}$, respectively; Fig. 3c).

In the second experiment, the number of shore crab settlers on the surface collectors were much lower (average 0.4 collector $^{-1}$ ) and none were found on the bottom collectors (excluding the depth factor from the analysis). Although a trend of higher densities of set- 


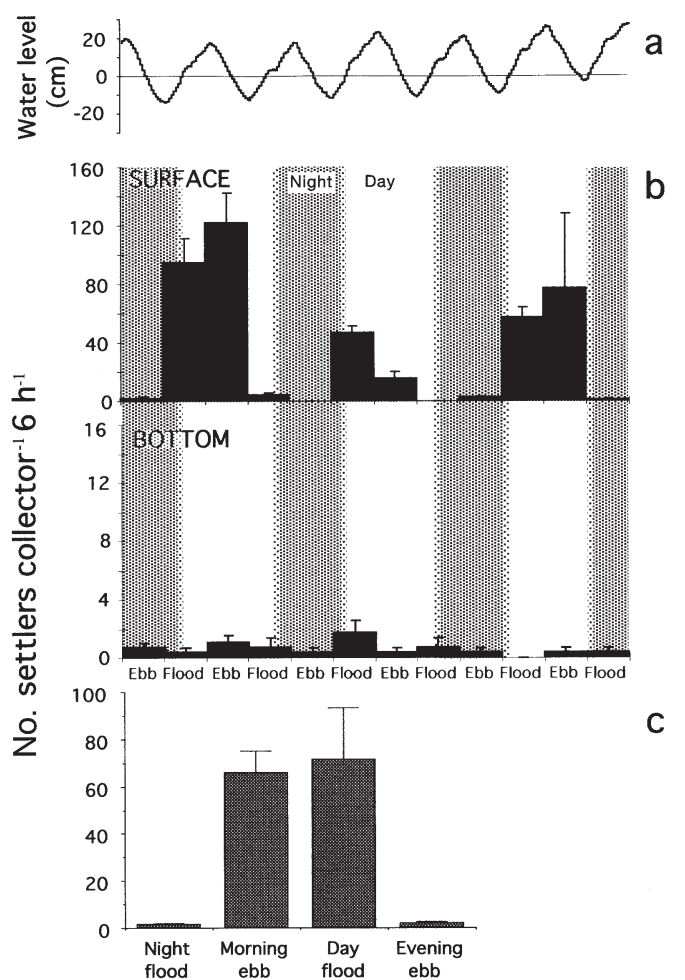

Fig. 3. Carcinus maenas. Field Expt 1: (a) tidal changes in water level. (b) Mean no. of shore crab settlers (megalopae and firstinstar crabs; $+\mathrm{SE}, \mathrm{n}=3$ ) on artificial settlement collectors located either at the surface or close to the bottom (at $9 \mathrm{~m}$ depth) and immersed for approximately $6.15 \mathrm{~h}$ to sample semidiurnal ebb and flood tides. Note the different scales used in the surface and bottom graphs. (c) Data pooled from the $3 \mathrm{~d}$ experiment for the 4 tidal-light periods sampled each day at the surface

Table 1. Carcinus maenas. Field Expt 1. $\log (x+1)$-transformed no. settlers (megalopae + first-instars) as a function of tidal-light phase (morning ebb, day flood, evening ebb, night flood), depth (bottom, surface), and day (Day 1 to 3). Three-factor mixed-ANOVA models $\left({ }^{*} p<0.05,{ }^{* * *} p<0.001,{ }^{* * * *} p<0.0001\right.$, ns: $p>0.05$ )

\begin{tabular}{|llrc|}
\hline Source of variation & df & \multicolumn{1}{c|}{ SS } & $F$ \\
\hline Tidal-light phase (A) & 3 & 9.59 & $30.0^{* * *}$ \\
Depth (B) & 1 & 13.14 & $27.0^{* *}$ \\
Day (C) & 2 & 0.85 & $8.2^{* * *}$ \\
A $\times$ B & 3 & 9.15 & $73.0^{* * * *}$ \\
A C & 6 & 0.64 & $2.0 \mathrm{~ns}$ \\
B $\times$ C & 2 & 0.97 & $9.3^{* * *}$ \\
A $\times$ B $\times$ C & 6 & 0.25 & $0.8 \mathrm{~ns}$ \\
Residual & 48 & 2.50 & \\
\hline
\end{tabular}

tlers on the surface collectors in morning ebb and day flood samples (on average 0.9 and 0.7 settlers collector $^{-1}$, respectively) compared to evening ebb and night flood samples $\left(0.2\right.$ and 0 settlers collector $^{-1}$, respectively) was observed, similar to the first experiment, no significant effect was found (Fig. 4a, Table 2).
No difference was seen between ebb- and flood-tide samples (average 0.6 and 0.3 settlers collector $^{-1}$, respectively). However, high numbers of megalopae were caught in the concurrently performed plankton net tows, but with the opposite temporal pattern; significantly higher densities were sampled at night compared to the day (average 35 and 3.0 megalopae $100 \mathrm{~m}^{-3}$, respectively) on all days (Fig. 4b, Table 2). Water surface salinity showed small daily variations

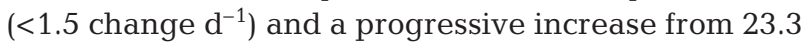
to 25.8 during the $10 \mathrm{~d}$ experimental period. Surface temperature was similarly stable and showed a corresponding decrease from 20.3 to $18^{\circ} \mathrm{C}$.

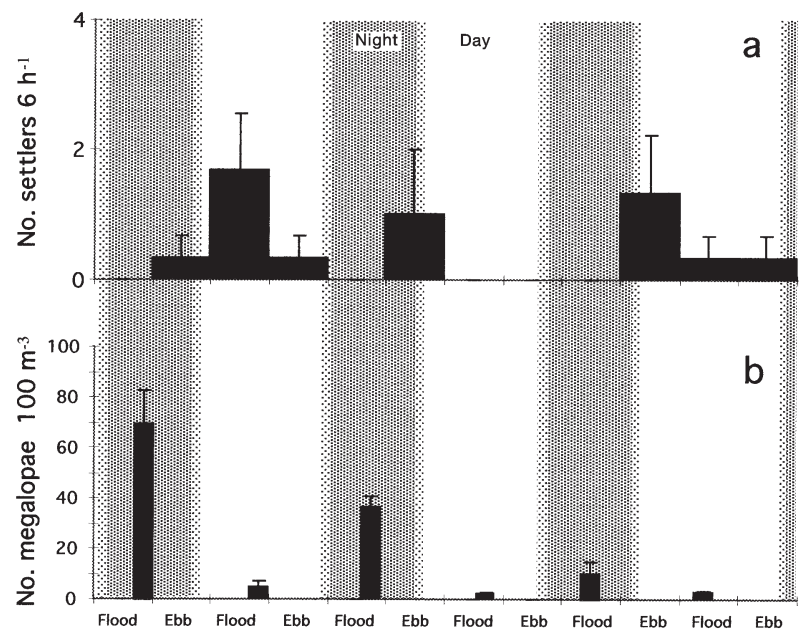

Fig. 4. Carcinus maenas. Field Expt 2. (a) Mean no. of shore crab settlers (megalopae and first-instar crabs; $+\mathrm{SE}, \mathrm{n}=3$ ) sampled with artificial settlement collectors during ebb and flood tides at day and night, located at the surface. (b) Mean no. of megalopae $100 \mathrm{~m}^{-3}(+\mathrm{SE}, \mathrm{n}=3)$ collected with surface plankton net tows during the day and night. Note the different scales used in the 2 graphs

Table 2. Carcinus maenas. Field Expt 2: $\log (x+1)$-transformed no. settlers on collectors as a function of tidal-light phase and day. $\log (x+1)$-tranformed no. megalopae in plankton net tows as a function of light phase (daylight, night) and day. Twofactor mixed-ANOVA models $\left({ }^{* * * *} \mathrm{p}<0.0001, \mathrm{~ns}: \mathrm{p}>0.05\right)$

\begin{tabular}{|lrcc|}
\hline Source of variation & df & SS & $F$ \\
\hline Collectors & & & \\
Tidal-light phase (A) & 3 & 0.22 & $1.9 \mathrm{~ns}$ \\
Day (B) & 2 & 0.06 & $0.8 \mathrm{~ns}$ \\
A $\times$ B & 6 & 0.23 & $1.1 \mathrm{~ns}$ \\
Residual & 24 & 0.87 & \\
Plankton net & & & \\
Light phase (A) & 1 & 3.64 & $46.0^{* * * *}$ \\
Day (B) & 2 & 0.52 & $3.3 \mathrm{~ns}$ \\
A $\times$ B & 2 & 0.60 & $3.8 \mathrm{~ns}$ \\
Residual & 11 & 0.87 & \\
\hline
\end{tabular}




\section{Laboratory experiments — postlarval emigration}

Recovery rates of megalopae were high in both experiments ( $>95 \%$ on average). Few megalopae were found dead ( $<3 \%$ on average). The water flow rate to each tank was measured at the beginning and at the end of each experiment. The average flow rate varied from 1.8 to $3.01 \mathrm{~min}^{-1}$ but did not differ significantly between treatments in the 2 experiments (see Tables 3 \& 6). Further, no significant correlation was found between the flow rate and the emigration rate $\mathrm{h}^{-1}$ in each tank (linear regression analysis: $p>0.05$; $r^{2}=0.02 ; n=47$ ), suggesting little linear effect of flow rate on megalopal emigration in the experiment. Water temperature and salinity in the mesocosms varied between 15 and 21 and between 23 and $30^{\circ} \mathrm{C}$, respectively, during the 2 experiments.

\section{Expt 1: effect of habitat and food}

Over $60 \%$ of the megalopae emigrated from the tanks during the $40 \mathrm{~h}$ experiment. Close to $80 \%$ of the total emigration occurred during the night, with a peak occurring at dusk and early night. Few megalopae emigrated during the initial daylight hours, and most of this emigration occurred within the first $30 \mathrm{~min}$ of the experiment. This temporal pattern was found irrespective of experimental treatment or when the experiment was initiated (Fig. 5). Virtually no emigration occurred after the first night in the last $24 \mathrm{~h}$ of the experiment $(<1 \%)$, although several live postlarvae were found in the tanks at the termination of the experiment (average 3.4 megalopae tank ${ }^{-1}$ ).

Proportional emigration rate of megalopae was significantly higher from sand compared to mussel habitats (average 79 and $45 \%$, respectively), irrespective of food treatment. This habitat effect was significant in all trials, but emigration rate within habitat treatments varied between trials causing a significant habitat $\times$ trial interaction effect (Fig. 6a, Table 3; SNK-test, $\mathrm{p}<0.05)$. Emigration rates were significantly lower in habitats with food (average 58\%) than in habitats without food (average $66 \%$ ) in both habitats, although the effect of food appeared smaller in sand (Fig. 6a, Table 3). The proportion of megalopae that emigrated during daylight was significantly higher from the sand habitat (average 25\%) than from the mussel habitat (average 15\%) indicating that megalopae emigrated earlier from the sand habitat; no significant effect of food was found (Fig. 6b, Table 3). Significantly higher losses of settlers occurred in sand with food $(7.0 \%)$ than in mussel with food $(1.5 \%)$, possibly indicating cannibalism between settlers in sand. However, no significant differences were found between habitats in treatments without food, or between food treatments, causing a significant habitat $\times$ food interaction effect (Fig. 6c, Table 3; SNK-test, $\mathrm{p}<0.05$ ). Proportional metamorphosis rate at the end of the $40 \mathrm{~h}$ experiment varied significantly between trials and was significantly higher in mussel than in sand treatments (on average $51 \%$ and $41 \%$, respectively) but similar between food treatments (Fig. 6d, Table 3), indicating that habitat type, but not food levels, affected the development TTM. An additional analysis performed only on the emigrated megalopae showed the opposite pattern; proportional metamorphosis rate was significantly higher in megalopae emigrating from the sand treatments than in megalopae from mussel treatments (average $29 \%$ and 19\%, respectively; Table 3), indicating that later stage megalopae emigrated from the sand compared to mussel treatments. No significant effect of food was found.

TTM in the megalopae that remained at the end of the last 2 trials was significantly longer in emigrated megalopae (average $2.2 \mathrm{~d}$ ) than in the megalopae recovered from the experimental tanks (average $1.3 \mathrm{~d}$ ) in all treatment combinations (Fig. 7, Table 4). No significant effect of habitat or food was detected.

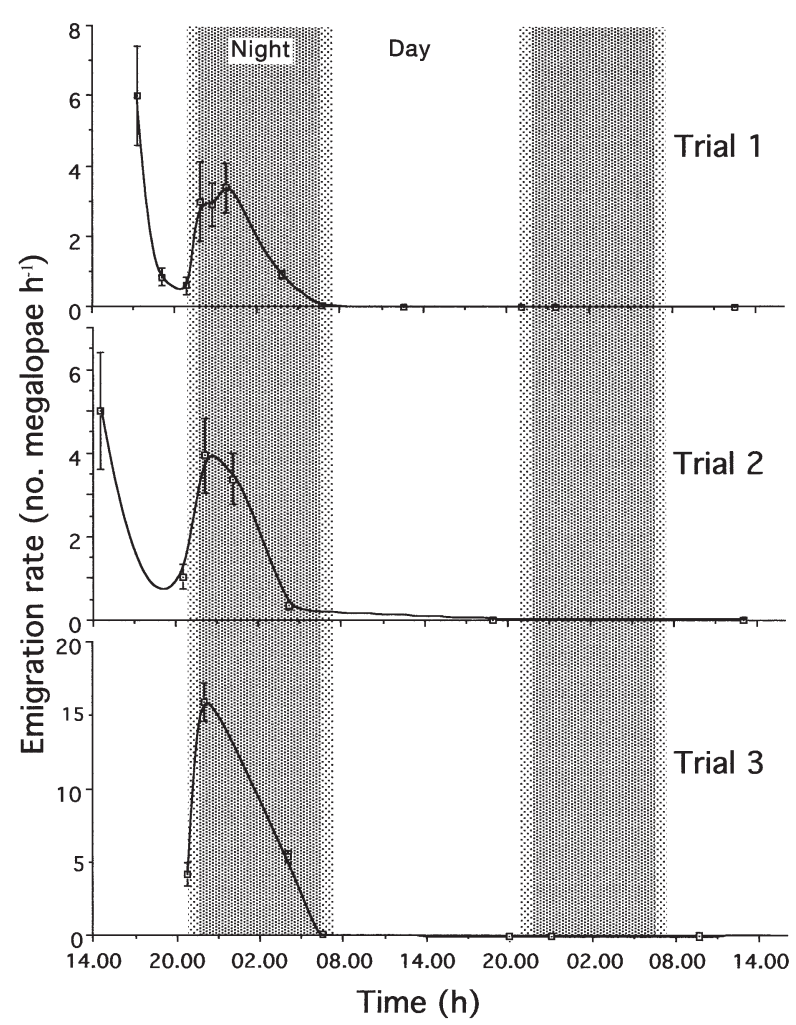

Fig. 5. Carcinus maenas. Laboratory Expt 1: Temporal pattern of emigration. Mean no. of shore crab megalopae $( \pm \mathrm{SE}, \mathrm{n}=8)$ that emigrated $\mathrm{h}^{-1}$ from sand and mussel habitats during the $40 \mathrm{~h}$ experiment in Trials 1 to 3 . Note the different scales used in the 3 graphs 

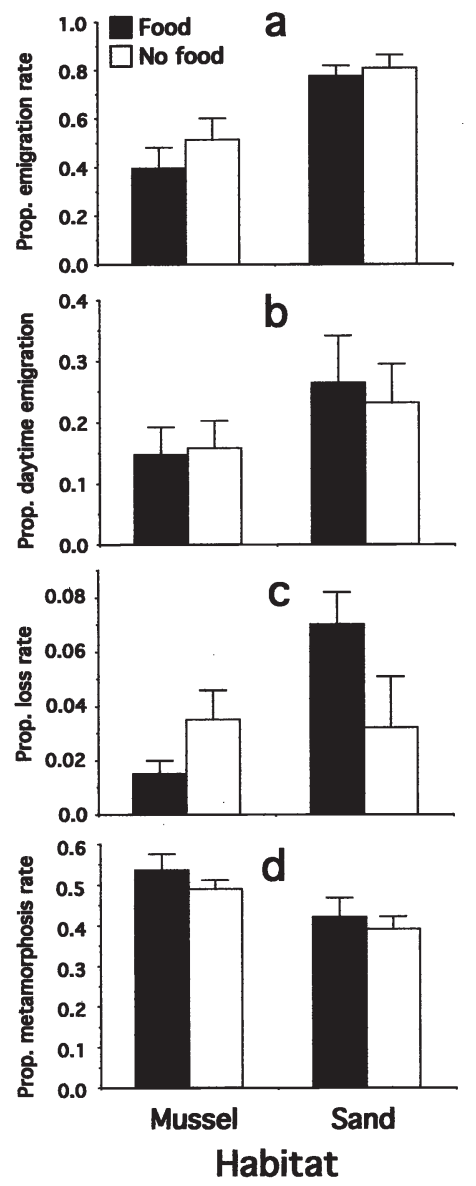

Fig. 6. Carcinus maenas. Laboratory Expt 1: effect of habitat and food. (a) Mean proportional emigration rate (per $40 \mathrm{~h}$ ) of megalopae, (b) mean proportion of the emigration occurring during daylight, (c) mean proportional loss of settlers (per $40 \mathrm{~h}$ ), and (d) mean proportional metamorphosis rate (per $40 \mathrm{~h}$ ) of megalopae $(+\mathrm{SE}, \mathrm{n}=6)$ in mussel and sand habitats, with or without an excess of food

The complementary cup experiment showed that TTM and cannibalism increased significantly with megalopal density (Fig. 8, Table 5). TTM was significantly shorter at megalopal densities 2 and 4 compared to the higher densities (SNK-test, $\mathrm{p}<0.05$ ), whereas food had no significant effect on metamorphosis rate. Cannibalistic rates increased significantly with megalopal densities in both food treatments; they were sig- nificantly higher in the treatments without food, but only at the higher densities, causing a significant density $\times$ food interaction effect (Table 5 ; SNK-test, $\mathrm{p}<$ 0.05). These results suggest that care should be taken to use food and low and similar megalopal densities when estimating TTM in shore crabs to avoid high rates of cannibalism and biased estimates of metamorphosis rates. Since densities and cannibalistic rates varied between treatments in the TTM analysis of Expt 1, the result should be interpreted cautiously.

\section{Expt 2: effect of settlement density}

On average, $53 \%$ of megalopae emigrated from the tanks during the 12 to $18 \mathrm{~h}$ experiment. Emigration rates were low until dusk when they peaked (average $31 \%$ of all emigration occurred during the $1.5 \mathrm{~h}$ of simulated dusk) and remained high during the night (89\% of the total emigration occurred at dusk and night).

Proportional emigration rate varied significantly between trials, but no significant effect of density was found, although an increasing trend was seen from 12 to 324 megalopae (48 to $62 \%$ emigration; Fig. 9a, Table 6). The proportion of megalopae that emigrated during daylight increased significantly with larval density, but only in 2 of the trials, causing a significant density $\times$ trial interaction effect (Fig. 9b, Table 6). This result indicates that megalopae may leave the habitats earlier at high conspecific densities. Losses of settlers were significantly higher ( 3 to $5 \%$ ) at densities of 36 to 324 megalopae compared to the lowest density, in which no loss occurred (Fig. 9c, Table 6), indicating cannibalism between settlers at high megalopal densities. Proportional metamorphosis rates were low and similar in the second experiment (average 6 to $13 \%$ in the 3 different trials) and density treatments did not significantly affect the total metamorphosis rate or

Table 3. Carcinus maenas. Laboratory Expt 1: effect of habitat and food. Water flow ( $\left.\mathrm{min}^{-1}\right)$, proportional megalopal emigration, proportion of total emigration occurring during daylight, proportional loss of megalopae, proportional metamorphosis rate of emigrated and remaining megalopae, and proportional metamorphosis rate of emigrated megalopae as a function of habitat (mussel, sand), food level (surplus of food, no food), and trial (Trials 1 to 3 ). Three-factor ANOVA models $\left({ }^{*} p<0.05,{ }^{* *} p<0.01\right.$, $\left.{ }^{* * * *} \mathrm{p}<0.0001, \mathrm{~ns}: \mathrm{p}>0.05\right)$

\begin{tabular}{|c|c|c|c|c|c|c|c|c|c|c|c|c|c|}
\hline \multirow[t]{2}{*}{$\begin{array}{l}\text { Source of } \\
\text { variation }\end{array}$} & \multirow[t]{2}{*}{ df } & \multicolumn{2}{|c|}{ Water flow } & \multicolumn{2}{|c|}{ Prop. emigr. } & \multicolumn{2}{|c|}{$\begin{array}{l}\text { Prop. day } \\
\text { emigr. }\end{array}$} & \multicolumn{2}{|c|}{ Prop. loss } & \multicolumn{2}{|c|}{$\begin{array}{c}\text { Prop. } \\
\text { metam. all }\end{array}$} & \multicolumn{2}{|c|}{$\begin{array}{l}\text { Prop. metam. } \\
\text { emigr. }\end{array}$} \\
\hline & & SS & $F$ & SS & $F$ & SS & $F$ & SS & $F$ & SS & $F$ & $\mathrm{SS}$ & $F$ \\
\hline Habitat (A) & 1 & 25.2 & $2.2 \mathrm{~ns}$ & 0.688 & $226.9^{* * * *}$ & 0.054 & $9.1^{*}$ & 0.004 & $5.1^{*}$ & 0.069 & $11.3^{* *}$ & 0.058 & $5.1^{*}$ \\
\hline Food (B) & 1 & 4.9 & $0.4 \mathrm{~ns}$ & 0.035 & $11.7^{* *}$ & 0.001 & $0.1 \mathrm{~ns}$ & 0.001 & $0.6 \mathrm{~ns}$ & 0.008 & $1.3 \mathrm{~ns}$ & 0.001 & $0.1 \mathrm{~ns}$ \\
\hline Trial (C) & 2 & 86.4 & $3.8 \mathrm{~ns}$ & 0.513 & $84.7^{* * * *}$ & 0.294 & $24.6^{* * * *}$ & 0.002 & $1.2 \mathrm{~ns}$ & 0.058 & $4.8^{*}$ & 0.096 & $4.3^{*}$ \\
\hline $\mathrm{A} \times \mathrm{B}$ & 1 & 3.4 & $0.3 \mathrm{~ns}$ & 0.009 & $3.1 \mathrm{~ns}$ & 0.003 & $0.5 \mathrm{~ns}$ & 0.005 & $6.3^{*}$ & 0.000 & $0.1 \mathrm{~ns}$ & 0.000 & $0.0 \mathrm{~ns}$ \\
\hline $\mathrm{A} \times \mathrm{C}$ & 2 & 5.3 & $0.2 \mathrm{~ns}$ & 0.059 & $9.7^{* *}$ & 0.044 & $3.7 \mathrm{~ns}$ & 0.001 & $0.8 \mathrm{~ns}$ & 0.008 & $0.6 \mathrm{~ns}$ & 0.032 & $1.4 \mathrm{~ns}$ \\
\hline $\mathrm{B} \times \mathrm{C}$ & 2 & 19.8 & $0.9 \mathrm{~ns}$ & 0.012 & $2.0 \mathrm{~ns}$ & 0.014 & $1.2 \mathrm{~ns}$ & 0.005 & $2.9 \mathrm{~ns}$ & 0.018 & $1.5 \mathrm{~ns}$ & 0.037 & $1.7 \mathrm{~ns}$ \\
\hline $\mathrm{A} \times \mathrm{B} \times \mathrm{C}$ & 2 & 7.0 & $0.3 \mathrm{~ns}$ & 0.009 & $1.4 \mathrm{~ns}$ & 0.004 & $0.4 \mathrm{~ns}$ & 0.001 & $0.9 \mathrm{~ns}$ & 0.005 & $0.4 \mathrm{~ns}$ & 0.020 & $0.9 \mathrm{~ns}$ \\
\hline Residual & 12 & 126.7 & & 0.036 & & 0.071 & & 0.010 & & 0.073 & & 0.136 & \\
\hline
\end{tabular}




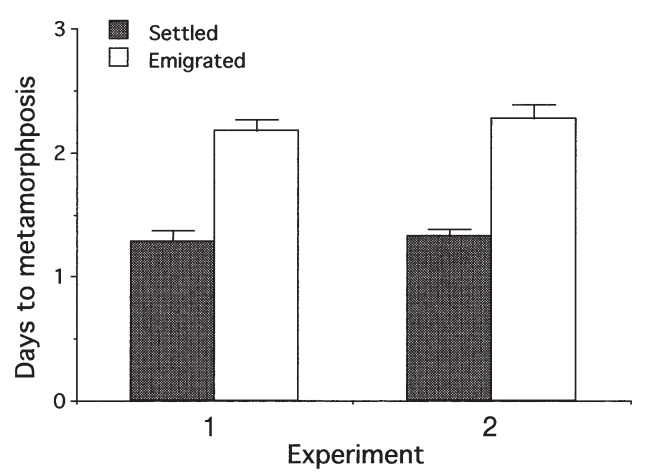

Fig. 7. Carcinus maenas. Laboratory Expts 1 and 2: (a) mean no. of days to metamorphosis $( \pm \mathrm{SE}, \mathrm{n}=3$ ) in megalopae that emigrated or remained in the habitat tanks

Table 4. Carcinus maenas. Laboratory Expt 1: time to metamorphosis (TTM, d) in megalopae remaining at the end of the experiment as a function of settlement behavior (emigrated, stayed), habitat type, and food levels. Three-factor ANOVA models $\left({ }^{* * *} \mathrm{p}<0.001, \mathrm{~ns}: \mathrm{p}>0.05\right)$

\begin{tabular}{|lccr|}
\hline Source of variation & df & SS & $F$ \\
\hline Settlement behavior (A) & 1 & 4.52 & $31.3^{* * *}$ \\
Habitat (B) & 1 & 0.10 & $0.7 \mathrm{~ns}$ \\
Food (C) & 1 & 0.04 & $0.3 \mathrm{~ns}$ \\
$\mathrm{~A} \times \mathrm{B}$ & 1 & 0.01 & $0.1 \mathrm{~ns}$ \\
$\mathrm{~A} \times \mathrm{C}$ & 1 & 0.06 & $0.4 \mathrm{~ns}$ \\
$\mathrm{~B} \times \mathrm{C}$ & 1 & 0.00 & $0.0 \mathrm{~ns}$ \\
$\mathrm{~A} \times \mathrm{B} \times \mathrm{C}$ & 1 & 0.00 & $0.0 \mathrm{~ns}$ \\
Residual & 8 & 1.16 & \\
\hline
\end{tabular}

regarding metamorphosis rate in the emigrated megalopae (6 to $10 \%$ and 0 to $4 \%$ at the 4 density treatments, respectively; Fig. 9d, Table 6).

TTM in the megalopae that remained at the end of the trials was significantly longer in emigrated megalopae (average $2.3 \mathrm{~d}$ ) than in megalopae recovered from the experimental tanks (average $1.3 \mathrm{~d}$ ) in all treatment combinations (Fig. 7, Table 7). No significant effect of density was detected. Megalopal densities were similar and loss rates were low and similar between tank and bucket treatments (6.7 and 6.6\% loss, respectively) suggesting little experimental artifact from cannibalism in the cups.

To further assess the effect of development stage on emigration, a simple linear regression analysis was performed between metamorphosis $\mathrm{h}^{-1}$ and proportional emigration $\mathrm{h}^{-1}$ (dependent variable) in each treatment combination from both experiments. This supplementary analysis demonstrated a significant negative correlation between metamorphosis rate and emigration rate $\left(F=13.3, \mathrm{df}=1,46, \mathrm{p}<0.001, \mathrm{r}^{2}=0.22\right.$; Fig. 10), although the regression line explained $<23 \%$ of the variation.

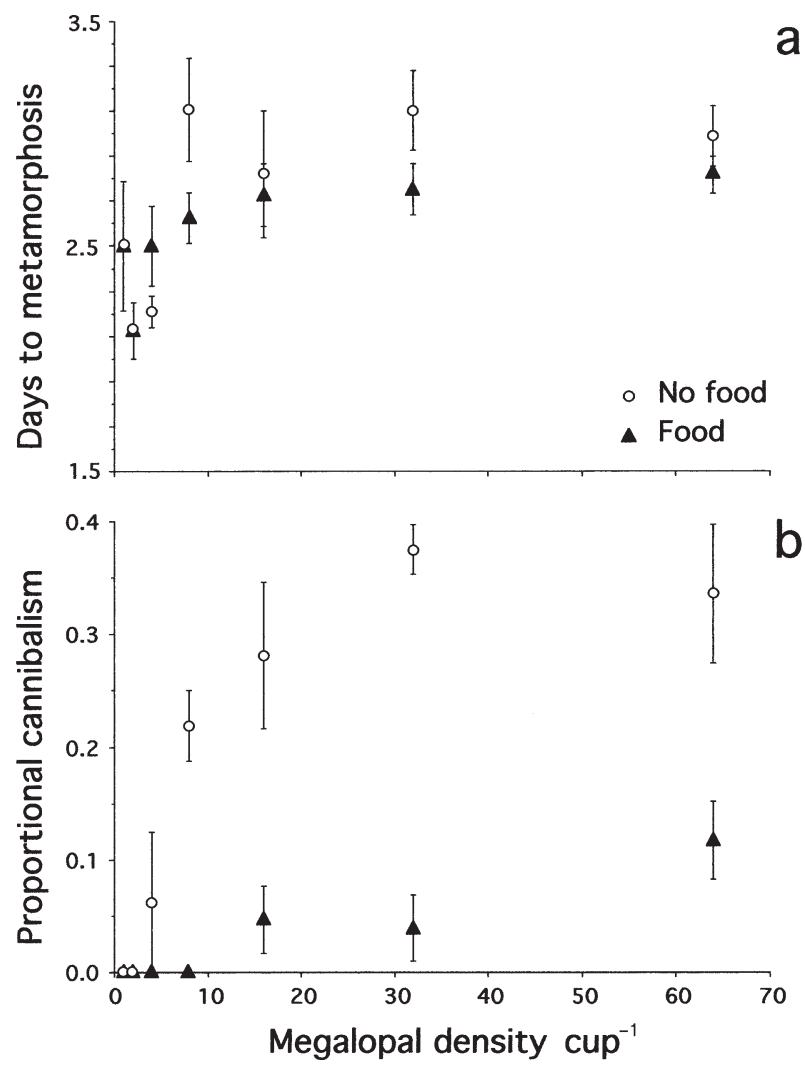

Fig. 8. Carcinus maenas. Cup experiment of metamorphosis and cannibalism. (a) Mean no. of days to metamorphosis, and (b) mean proportional loss of megalopae $( \pm \mathrm{SE}, \mathrm{n}=3)$ as a function of megalopal density and food.

\section{DISCUSSION}

Both field and laboratory experiments demonstrated that many shore crab megalopae are associated with benthic habitats during daylight hours only and actively emigrate at dusk, even from optimal settlement conditions, to swim in the water column at night. These results contrast with the 'settle and stay hypothesis' (Bell \& Westoby 1986) and settlement models in the

Table 5. Carcinus maenas. Laboratory Expt 1: density and food effects on metamorphosis. Time to metamorphosis (TTM, d) and proportional cannibalism as a function of megalopal density (1 to 64 larvae $\mathrm{cup}^{-1}$ ), and food levels (food, no food). Two-factor-mixed ANOVA models $\left({ }^{*} \mathrm{p}<0.05\right.$, $\left.{ }^{* * *} \mathrm{p}<0.001,{ }^{* * * *} \mathrm{p}<0.0001, \mathrm{~ns}: \mathrm{p}>0.05\right)$

\begin{tabular}{|lrrrrr|}
\hline \multirow{2}{*}{$\begin{array}{l}\text { Source of } \\
\text { variation }\end{array}$} & \multirow{2}{*}{ df } & \multicolumn{2}{c}{ TTM } & \multicolumn{2}{c|}{ Prop. cannibalism } \\
& & SS & $F$ & SS & $F$ \\
\hline Density (A) & 6 & 4.69 & $5.82^{* * *}$ & 0.45 & $16.0^{* * * *}$ \\
Food (B) & 1 & 0.18 & $1.44(\mathrm{~ns})$ & 0.33 & $9.46^{* *}$ \\
A $\times$ B & 6 & 0.77 & $0.96(n s)$ & 0.21 & $7.41^{* * * *}$ \\
Residual & 42 & 5.63 & & 0.20 & \\
\hline
\end{tabular}




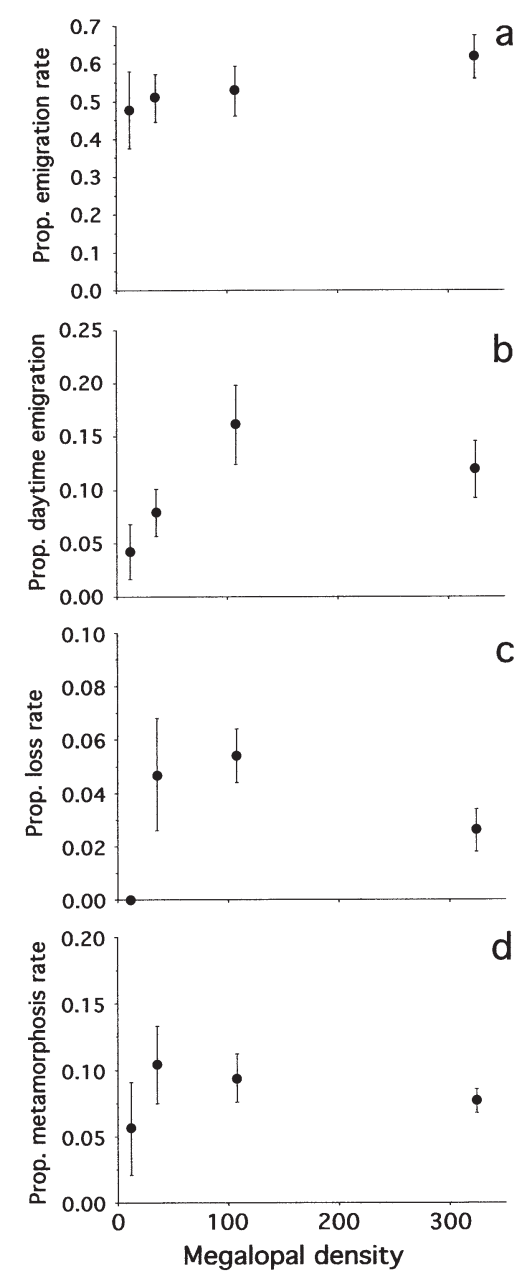

Fig. 9. Carcinus maenas. Laboratory Expt 2: effect of settlement density. (a) Mean proportional emigration rate (per $15 \mathrm{~h})$, (b) mean proportion of the emigration occurring during daylight, (c) mean proportional loss of settlers (per $15 \mathrm{~h})$, and (d) mean proportional metamorphosis rate (per $15 \mathrm{~h})( \pm \mathrm{SE}, \mathrm{n}=6)$ in mussel habitats with food as a function of megalopal density

American lobster (Barshaw \& Rich 1997), which state that postlarvae will settle into the first settlement habitat they encounter, irrespective of habitat quality and developmental stage. In shore crabs, settlement is not an irreversible process after the megalopa has found a settlement habitat, but involves 2 separate behavioral components: (1) the selection of a benthic habitat during the day, (2) the choice to stay or emigrate the fol- lowing night. We will argue that: (1) the habitat choice is determined by the availability of refuges from predation, and less affected by food levels and conspecific densities; (2) developmental stage is the main factor determining permanent settlement or emigration at dusk, and not the quality of the habitat; (3) light is the physical factor inducing the temporary settlement and emigration of postlarvae from benthic habitats in the Swedish microtidal system, and not cues associated with tidal changes. We will also propose a settlement model where diel differences in predation risk between the settlement habitat and the plankton are the major ultimate factor in shore crab settlement behavior.

\section{Physical factors affecting settlement behavior in Swedish shore crabs}

Tides

Tides appeared to have little influence on the swimming and settlement behavior in Swedish shore crabs. Abundance of shore crab megalopae on artificial settlement collectors did not vary in relation to the tidal phase, neither on the surface nor on the deep collectors, in spite of a clear tidal variation in the water level of about $0.3 \mathrm{~m}$. Although the tidal phase could not be separated from the tidal-light phase assessed, almost identical numbers of megalopae were collected each day in the morning ebb and the day flood samples, and in the evening ebb and night flood samples, suggesting little effect of tides alone.

The larvae of many estuarine animals that develop in offshore waters use selective tidal stream transport to disperse from the coast and return to estuarine nursery areas for settlement (see Forward \& Tankersley 2001 for review). Such vertical migration behavior has been documented for shore crab larvae from mesotidal areas in Europe. In these areas, shore crab zoea larvae display an inheritable endogenous circatidal migration rhythm (Zeng \& Naylor 1996a,c, Duchêne \& Queiroga

Table 6. Carcinus maenas. Laboratory Expt 2: effect of settlement density. Water flow $\left(1 \mathrm{~min}^{-1}\right)$, proportional megalopal emigration, proportion of total emigration occuring during daylight, proportional loss of megalopae (angular-transformed), proportional metamorphosis rate of emigrated and remaining megalopae and proportional metamorphosis rate of emigrated megalopae as a function of megalopal density (12 to 324 larvae tank $^{-1}$ ), and trial (Trials 1 to 3 ). Two-factor mixed ANOVA models $\left({ }^{* *} \mathrm{p}<0.01,{ }^{* * * *} \mathrm{p}<0.0001\right.$, ns: $\mathrm{p}>0.05)$

\begin{tabular}{|c|c|c|c|c|c|c|c|c|c|c|c|c|c|}
\hline \multirow[t]{2}{*}{$\begin{array}{l}\text { Source of } \\
\text { variation }\end{array}$} & \multirow[t]{2}{*}{$\mathrm{df}$} & \multicolumn{2}{|c|}{ Water flow } & \multicolumn{2}{|c|}{ Prop. emigr. } & \multicolumn{2}{|c|}{$\begin{array}{l}\text { Prop. day } \\
\text { emigr. }\end{array}$} & \multicolumn{2}{|c|}{ Prop. loss } & \multicolumn{2}{|c|}{$\begin{array}{c}\text { Prop. } \\
\text { metam. all }\end{array}$} & \multicolumn{2}{|c|}{$\begin{array}{l}\text { Prop. metam. } \\
\text { emigr. }\end{array}$} \\
\hline & & SS & $F$ & SS & $F$ & SS & $F$ & SS & $F$ & SS & $F$ & SS & $F$ \\
\hline Density (A) & 3 & 157.8 & $1.4 \mathrm{~ns}$ & 0.063 & $2.2 \mathrm{~ns}$ & 0.048 & $30.8^{* * * *}$ & 0.173 & $6.3^{* *}$ & 0.008 & $1.0 \mathrm{~ns}$ & 0.004 & $1.2 \mathrm{~ns}$ \\
\hline Trial (B) & 2 & 20.6 & $0.9 \mathrm{~ns}$ & 0.442 & $12.4^{* *}$ & 0.053 & $4.0 \mathrm{~ns}$ & 0.001 & $0.1 \mathrm{~ns}$ & 0.024 & $4.1 \mathrm{~ns}$ & 0.007 & $3.9 \mathrm{~ns}$ \\
\hline $\mathrm{A} \times \mathrm{B}$ & 6 & 73.1 & $0.3 \mathrm{~ns}$ & 0.107 & $1.9 \mathrm{~ns}$ & 0.040 & $12.7^{* * * *}$ & 0.033 & $0.6 \mathrm{~ns}$ & 0.018 & $1.1 \mathrm{~ns}$ & 0.005 & $0.8 \mathrm{~ns}$ \\
\hline Residual & 12 & 447.2 & & 0.115 & & 0.006 & & 0.111 & & 0.033 & & 0.012 & \\
\hline
\end{tabular}


Table 7. Carcinus maenas. Laboratory Expt 2: time to metamorphosis (TTM, d) in megalopae remaining at the end of the experiment as a function of settlement behavior (emigrated, not emigrated), and settlement density. Two-factor mixedANOVA model $\left({ }^{* *} \mathrm{p}<0.01, \mathrm{~ns}: \mathrm{p}>0.05\right)$

\begin{tabular}{|lrcc|}
\hline Source of variation & df & SS & $F$ \\
\hline Settlement behavior (A) & 1 & 7.03 & $71.5^{* *}$ \\
Density (B) & 3 & 0.58 & $0.7 \mathrm{~ns}$ \\
A $\times$ B & 3 & 0.29 & $0.4 \mathrm{~ns}$ \\
Residual & 16 & 4.25 & \\
\hline
\end{tabular}

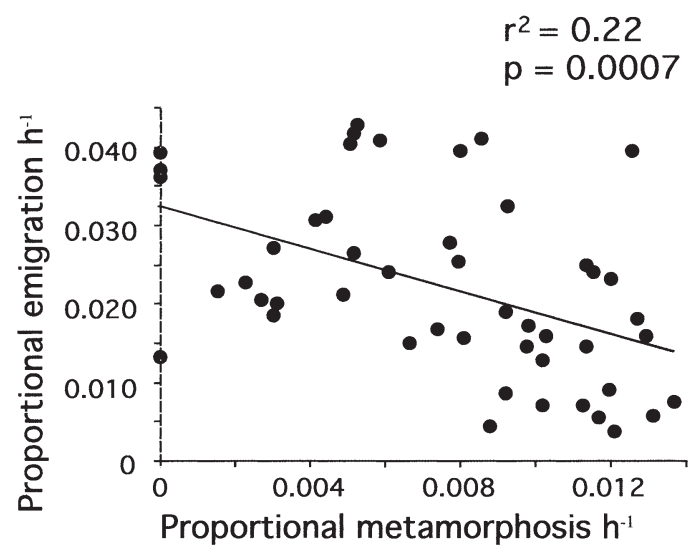

Fig. 10. Carcinus maenas. Laboratory Expts 1 and 2: relationship between the metamorphosis rate $\mathrm{h}^{-1}$ and the proportional emigration rate $\mathrm{h}^{-1}$ of megalopae from all treatments combined (linear regression analysis, $\mathrm{n}=48$ )

2001), and peak surface abundance and metamorphosis of megalopae occur at local high tide (Zeng \& Naylor 1996b, Zeng et al. 1997, Queiroga 1998). The lack of a tidal pattern in the present study suggests that tides do not play an important role in the transport and settlement of shore crabs on the Swedish west coast. The present result is consistent with recent laboratory studies demonstrating a lack of endogenous circatidal vertical migration rhythms in Swedish shore crab zoea (Queiroga et al. 2002) and megalopae (T. Reinwald \& P-O. Moksnes, unpubl. data), and is in accordance with field studies showing that megalopal water column abundance in the Gullmarsfjord does not vary with the tidal phase (Queiroga et al. 2002). Thus, the present study supports the suggestion that different swimming and settlement behavior may exist within the same species from different tidal environments (see Queiroga et al. 2002 for further discussion).

The lack of a tidal signal in megalopal settlement abundance was not surprising considering that the microtidal conditions on the Swedish west coast do not produce any predictable changes in current speed or salinity (Moksnes \& Wennhage 2001, P-O. Moksnes unpubl. data). Swedish shore crabs could therefore not use tidally induced changes in salinity and turbulence as cues for selective tidal transport, such as those described for blue crab megalopae Callinectes sapidus Rathbun in meso-tidal areas (Tankersley et al. 1995, Welch et al. 1999, Welch \& Forward 2001). Further, since the tides are thought to play only a minor role in coastal water circulation in Sweden (Andersson \& Rahm 1985), vertical migration and clinging to benthic habitats in phase with local tides would be of little benefit for dispersal and recruitment in this system.

\section{Light}

Light appears to be the key physical factor affecting the temporal pattern of swimming and settlement in Swedish shore crabs. A clear diel pattern was found in megalopal abundance both on the collectors and in the water column, but at opposite phases; significantly higher densities were found on the collectors in the morning and in the day compared to the evening and night samples, whereas plankton-net tows showed significantly higher densities at night compared to the day. This result suggests that megalopae swim during the night and cling to benthic habitats during daylight. Although the field data supporting nocturnal swimming was limited to $6 \mathrm{~d}$ in this study, they are consistent with field studies demonstrating a significant negative correlation between the light intensity and the water column abundance of shore crab megalopal in the Gullmarsfjord (Queiroga et al. 2002). Light has been shown in numerous studies to affect the swimming behavior of marine larvae; most display a nocturnal type of diel vertical distribution (see Forward 1988 for review), including shore crab and blue crab megalopae from mesotidal areas, which are more abundant in surface waters during night flood tides compared to day flood tides (Forward \& Rittschof 1994, Zeng \& Naylor 1996b).

The field data in this study also suggest that many megalopae associated with benthic habitats during the day reenter the water column to swim as light decreases in the evening. Collectors that were sampled just before dusk in the first experiment had on average 30 times higher densities of megalopae than collectors sampled after dusk. A similar, although not significant, pattern was seen in the second experiment. This result is consistent with recent field experiments in which $>80 \%$ of megalopae emigrated from artificial collectors immersed for $>12 \mathrm{~h}$, presumably during the night (Moksnes \& Wennhage 2001).

This suggestion is supported by the laboratory experiments, which demonstrated that a large proportion of shore crab megalopae actively emigrate from potential settlement habitats, and that decreasing light intensity 
was a key factor initiating this behavior. On average, $58 \%$ of megalopae emigrated from the experimental tanks, and $85 \%$ of the total emigration occurred at the simulated dusk and in the early hours of the night, irrespective of habitat quality or when the postlarvae were introduced to the tanks. The start of emigration at dusk in the present study appears not to be endogenously controlled since very little emigration occurred at natural dusk, which occurred approximately $1 \mathrm{~h}$ before the simulated dusk in the laboratory. This is consistent with studies of shore crabs and blue crabs in meso-tidal areas where swimming behavior in late-stage megalopae appears to be controlled by exogenous cues (Tankersley \& Forward 1994, Zeng \& Naylor 1996b).

\section{Depth}

The field data suggest that megalopae settle mainly in shallow water. Very few megalopae were caught on the collectors placed at $9 \mathrm{~m}$ depth (average 0.3 megalopae collector ${ }^{-1} 24 \mathrm{~h}^{-1}$ ), whereas high numbers of postlarvae were concurrently caught on surface collectors. Predation probably did not affect this result, since densities of potential predators are very low on the open mud bottom where the collectors were located (P-O. Moksnes unpubl. data). Moreover, recent cage experiments performed in shallow nursery areas, where densities of potential predators are very high, found no effect of predation on settlement on the collectors (Moksnes \& Wennhage 2001). The low larval densities on the bottom collectors also appears not to be a result of the vertical distribution of megalopae since plankton samples taken with pumps from the surface and at $9 \mathrm{~m}$ depth at the same location showed similar densities of megalopae (Queiroga et al. 2002). The suggestions that megalopae actively select to settle at shallow depths is supported by studies in the British Isles where shore crab megalopae appear to settle mainly in high intertidal areas (Zeng et al. 1997). The proportion of firstinstar crabs was higher in samples from the bottom collectors compared to the surface collectors (average 38 and $2 \%$, respectively; low numbers of settlers on the deep samples precluded a statistical analysis), possibly indicating that megalopae very close to metamorphosis migrate towards the bottom to find a settlement habitat.

\section{Biological factors affecting emigration from benthic habitats}

Habitat quality

The benthic habitat had a large effect on both the settlement behavior and the development rate of shore crab megalopae, where the availability of refuges from predation appeared to be more important than food levels. Megalopae emigrated at significantly higher rates and at an earlier time from unstructured sand habitats compared to mussel habitats in the laboratory study (average 79 and $45 \%$ emigration, respectively), irrespective of food levels. Metamorphosis rates among emigrated megalopae were significantly higher in megalopae from sand habitats compared to mussel habitats, suggesting that megalopae emigrated in later developmental stages from the sand. This result is consistent with earlier laboratory and field experiments demonstrating that shore crab megalopae avoid open sand and actively settle in structurally complex habitats (Hedvall et al. 1998, Moksnes 2002) that provide a refuge from predation (Moksnes et al. 1998). The present study provides further support for the refuge value of the mussel habitat in demonstrating significantly lower levels of cannibalism between settlers in mussels compared to those in the sand habitat, although densities of settlers on average were $>2$ times higher in the former at the end of the experiment.

Interestingly, $>75 \%$ of the megalopae that emigrated from sand remained in the habitat until dusk before doing so, even when no food was present. Thus, although this result confirms earlier studies of shore crab habitat preference at settlement, it also suggests that habitat selection is not necessarily an instantaneous process where a habitat is accepted or rejected upon encounter, but that it may involve a delay of up to $12 \mathrm{~h}$ where the megalopae remain in the rejected habitat for the right light conditions before emigration. This behavior suggests that there must be a strong selective force to avoid the plankton during the day, possibly related to predation or dispersal.

The metamorphosis rate was significantly higher in postlarvae that had been introduced to mussel habitats (51\% per $40 \mathrm{~h}$ ) compared to sand habitats (41\% per $40 \mathrm{~h})$, irrespective of food levels. Accelerated metamorphosis in response to chemical or structural cues of the habitat has been demonstrated in many benthic invertebrate larvae (see review by Pechenik 1990), including blue crabs (Forward et al. 1994, 1996, Wolcott \& De Vries 1994, Brumbaugh \& McConaugha 1995, Moksnes et al. 1997). Little is known regarding exogenous cues affecting the metamorphosis rate in shore crabs. A recent study demonstrated that shore crabs from tidal areas display an endogenous circatidal rhythm of metamorphosis, which appears to be little affected by salinity, adult cues and the presence of gravel (Zeng et al 1997). This study is the first to provide indirect evidence that habitat cues may affect metamorphosis rate in shore crabs. Megalopae that were kept in small cups without refuge and food metamorphosed only a few days after postlarvae provided 
with optimal settlement conditions, suggesting that the ability of shore crabs to delay metamorphosis is limited to 1 or $2 \mathrm{~d}$, similar to that found in blue crabs.

Food levels had only a small effect on shore crab settlement behavior. Although emigration rates were significantly higher when food levels were lower, in both habitats the average effect was small (58 and 66\% emigration at high and low food levels, respectively). Further, low food levels did not induce earlier emigration, nor did it make megalopae in an earlier developmental stage leave. Food levels also did not have any effect on the settlers metamorphosis rate. These findings suggest that food levels are less important than the refuge value of the habitat in shore crab settlement.

\section{Settlement density}

Recent studies have demonstrated several important density-dependent interactions in young juvenile shore crabs resulting in decreased feeding rates and growth, increased emigration from nursery habitats and cannibalism within and between cohorts (Moksnes 1999). This study provides further support for density-dependent cannibalism between settlers, although this effect was small ( 0 to $5 \%$ mortality $15 \mathrm{~h}^{-1}$ ) when assessed under realistic conditions in the mesocosm tanks. Thus, megalopae that settle in habitats with low densities of conspecifics should receive a selective advantage, and therefore may have developed behaviors to avoid or emigrate from habitats with high number of settlers. However, this study provides little support of this hypothesis. We found only small effects of conspecific densities on the settlement behavior and development rates in shore crabs, even though very high natural settlement densities were assessed (equivalent to over 1700 megalopae $\mathrm{m}^{-2}$ ). Proportional emigration rates did not increase significantly with megalopal density, although a small trend of increased emigration was seen (48 to $62 \%$ ). When testing the emigration that occurred during the first hours of daylight, a significant density-dependent effect was found, suggesting that megalopae may leave habitats earlier at high conspecific densities. However, this effect was also small and only significant in 2 of the 3 trials.

Proportional metamorphosis rates were not significantly affected by megalopal density when assessed under realistic conditions in the mesocosm tanks. The results of the complementary cup experiment should be interpreted cautiously since the conditions were highly artificial and the significant effect of megalopal densities could have been affected by densitydependent cannibalism on metamorphosed individuals. Similar results have been found in blue crabs, where density-dependent effects on metamorphosis rates have been reported only in experiments performed in very small containers without any natural habitats (Forward et al. 1996) or in mesocosm tanks with sand, but not in tanks with seagrass, their preferred settlement habitat (Moksnes et al. 1997).

\section{Developmental stage}

The developmental stage of megalopae appears to be the key biological factor affecting the emigration from settlement habitats. Emigrated megalopae were in a significantly earlier developmental stage, and metamorphosed on average $1 \mathrm{~d}$ later than the megalopae that remained in the tanks. Further, a significant negative correlation was found between metamorphosis rate and emigration rates even though the data from all treatments were combined. This correlation was probably not caused by metamorphosis physically preventing emigration since most of the emigration occurred within the first 2 to $6 \mathrm{~h}$ of the 15 and $40 \mathrm{~h}$ experiments. The hierarchy of the key factors affecting postlarval emigration was best seen when contrasting developmental stage with habitat quality. In the second experiment, almost $50 \%$ of the megalopae emigrated from mussel habitats with an excess of food and low conspecific densities, although the emigrated postlarvae were only 2 to $3 \mathrm{~d}$ from metamorphosis, on average. Thus, megalopae appear to emigrate at dusk from optimal settlement habitats if the postlarvae are $>2 \mathrm{~d}$ from metamorphosis.

\section{Why do postlarvae emigrate?}

Although it appears clear that late-stage shore crab megalopae actively emigrate from settlement habitats at dusk, it is still puzzling why they exercise this behavior. There appears to be little selective advantage for a larva to leave an encountered settlement habitat when it is only a couple of days from metamorphosis and competent to occupy the juvenile habitat, particularly since it has only a limited ability to delay molt. Such a behavior would expose the larva to the supposedly high mortality rates in the plankton and the risk of not encountering another suitable settlement area before metamorphosis occurs. We will argue that both risks may be lower than generally perceived, and that the temporary settlement and emigration in shore crab postlarvae is an adaptation to reduce predation mortality in postlarvae not ready to metamorphose, while remaining close to nursery areas.

Larval migration towards the bottom during the day to avoid visual fish predators in the plankton has been 
suggested for many species (see Morgan 1995 for review), including crab larvae (Cronin \& Forward 1986, Tankersley et al. 1995), and the observed temporary daylight settlement in shore crabs may be an adaptation to reduce this. Moreover, clinging to a benthic habitat will also reduce transport from the shore. In contrast to planktonic fish predators, benthic crabs and shrimp are often more active during nighttime, and predation in shallow coastal habitats is generally believed to be higher at night (Raffaelli \& Hawkins 1996). One of the most abundant predators of shore crab settlers in shallow nursery areas, the brown shrimp Crangon crangon L. (Moksnes et al. 1998), has its peak foraging activity at night (Pihl \& Rosenberg 1984). Similarly, cannibalistic juvenile shore crabs display very high consumption rates of settlers during the night (P-O. Moksnes unpubl. data). The risk of predation may therefore be higher in benthic habitats than in the plankton at night when visual pelagic predators are less efficient. Thus, a diel difference in predation risk between benthic and planktonic habitats may be the major ultimate factor in shore crab settlement behavior, and may explain why postlarvae remained in habitats of poor quality during the day and emigrated at dusk in this study.

The idea that predation rates should be higher on postlarvae in settlement habitats compared to the plankton is not consistent with the conventional wisdom of very high mortality during the planktonic phase (Thorson 1950, Bell \& Westoby 1986). However, several authors have recently pointed out that data are not available to support the paradigm that mortality is higher in the plankton than on the sea floor (Ólafsson et al. 1994, Morgan 1995, 2001, Underwood \& Keough 2001), partly because of the practical difficulties in measuring planktonic mortality in the field. In contrast, an increasing number of studies of benthic invertebrates have demonstrated very high mortality rates of early juvenile stages (see Gosselin \& Qian 1997, Hunt \& Scheibling 1997 for review). In shore crabs, predation can cause very high settlement mortality in mussel beds and other structurally complex habitats (Hedvall et al. 1998, Moksnes et al. 1998, Moksnes 1999) because small epibenthic predators (mainly cannibalistic juvenile crabs and shrimp) concentrate in these habitats at high densities (Moksnes 2002). Conservative estimates from field experiments using cages and small bays as mesocosms, where larval and juvenile migration was accounted for, suggest that predation mortality in nursery habitats during settlement and the first-instar stage is $>15 \% \mathrm{~d}^{-1}$, on average (Moksnes 2002).

Support for higher mortality at settlement than in the plankton is provided by a simple life-history mortality model that calculates an indirect estimate of larval mortality in Swedish shore crabs using field data of settlement and post-settlement mortality to backcalculate how many individuals need to settle per female for 2 offspring to survive to reproduction. These calculations suggest that approximately $80 \%$ of larvae perish during the larval phase, equivalent to an average instantaneous larval mortality rate of $4 \%$ day $^{-1}(\mathrm{P}-$ O. Moksnes unpubl. data). This estimate is within the range of in situ estimates of mortality in decapod zoea larvae (1.6 to $22 \%$; mean $6.9 \%$ mortality d ${ }^{-1}$; Rumrill 1990) and suggests that settlement is a true bottleneck in the life-cycle of the shore crab, and that the risk of being eaten in the settlement habitat may be substantially higher than in the plankton. Thus, it may not be adaptive for megalopae that are $>2 \mathrm{~d}$ from metamorphosis to remain in a benthic habitat during the night because of the high risk of predation there, even if the settlement conditions are optimal, and even if they risk being transported away from any suitable settlement area. The latter risk may be smaller than generally perceived if shore crab megalopae have behavioral mechanisms in microtidal areas that control their on-shore transport. For example, larvae that display diel vertical migration within the water column may be able to exploit diurnal sea and land breezes to influence their dispersal (Shanks 1995), which may be a possible cross-shelf transport mechanism for shore crab larvae in microtidal systems. These suggestions present testable hypotheses and a challenge for future studies.

Based on the data presented here and in earlier studies (Hedvall et al. 1998, Moksnes 1999, 2002, Queiroga et al. 2002), and on the assumption of diel differences in predation risk, we propose the following conceptual model of settlement in shore crabs: (1) shore crab megalopae transported by currents to shallow $(<1 \mathrm{~m})$ coastal areas during daylight actively select habitats over a scale of meters to 10 s of meters. Predation risk is the dominant factor affecting habitat choice, and postlarvae select several structurally complex habitats that provide refuge from predation, avoiding open sand and mud, even if the food availability there is good. Some megalopae that only encounter unstructured bottom will temporarily settle there until dusk. This temporary settlement provides a spatial refuge from visual predators in the plankton and decreases the risk of being transported away from the coast and suitable settlement areas. (2) Using decreasing light intensity as a cue, most megalopae emigrate from habitats at dusk to swim in the water column colse to the surface during the night. Developmental stage of the megalopa is the main factor affecting emigration; postlarvae $>2 \mathrm{~d}$ from metamorphosis emigrate, irrespective of habitat quality. In megalopae that are closer to metamorphosis, remaining in the benthic habitat is affected by availability of refuges, but is less affected by the 
abundance of food or conspecific postlarvae. The nocturnal swimming behavior provides a spatial refuge from night-active benthic predators, and a temporal refuge from visual predators in the plankton. The megalopae will be transported away from the shore with the land breeze during the night and will swim in the neuston until the sea breeze brings them back to shore and they encounter a shallow habitat in daylight. (3) The diel pattern of temporary settlement and swimming repeats itself until a megalopa that is $<2 \mathrm{~d}$ from metamorphosis encounters a refuge habitat. The postlarva will then permanently settle and stay up to 2 nights in the habitat until metamorphosis occurs.

It is not known if this settlement model is applicable to other species or if postlarval emigration is unique to shore crabs, since few studies of other species have been designed to detect this behavior. Exceptionally, blue crab megalopae are believed to temporarily associate with the bottom at ebb tides when exercising selective flood-tide transport towards nursery habitats (Tankersley et al. 1995 and references therein). It is not clear, however, whether blue crab megalopae would continue this behavior if the preferred settlement habitat was encountered. We encourage further research with other species to assess if postlarval emigration from settlement habitats is common in benthic invertebrates. These studies could improve our understanding of the dynamic processes involved during settlement and our ability to accurately model habitat use and recruitment in marine organisms.

Acknowledgements. We thank Per Jonsson, Lewis Incze and 3 anonymous referees for helpful comments on the manuscript, Jacques van Montfrans for generously providing us with 'hogs hair' air-conditioning filter material, Björn af Ekenstam for help with the metamorphosis experiments, and the staff at Kristineberg Marine Research Station for providing excellent facilities. This research was made possible through a doctoral position to P-O.M. at the faculty of Mathematics and Natural Sciences at Göteborg University, and through grants from the Royal Swedish Academy of Sciences and 'Birgit och Birger Wåhlströms minnesfond för den Bohuslänska havs-och insjömiljön', all of which are kindly acknowledged.

\section{LITERATURE CITED}

Andersson L, Rahm L (1985) Heat balance of a shallow cove. Estuar Coast Shelf Sci 23:705-724

Barshaw DE, Able KW (1990) Tethering as a technique for assessing predation rates in different habitats: an evaluation using juvenile lobster Homarus americanus. Fish Bull 88:415-417

Barshaw DE, Rich DR (1997) An analysis of substrate selection by postlarval American lobsters, Homarus americanus, using a dynamic optimization model. Oikos 80:554-564

Bell JD, Westoby M (1986) Variation in seagrass height and density over a wide spatial scale: effects on common fish and decapods. J Exp Mar Biol Ecol 104:275-296
Botero L, Atema J (1982) Behaviour and substrate selection during larval settling in the lobster Homarus Americanus. J Crustac Biol 2:59-69

Brumbaugh RD, McConaugha JR (1995) Time to metamorphosis of blue crab Callinectes sapidus megalopae: effects of benthic macroalgae. Mar Ecol Prog Ser 129: $113-118$

Colman JS (1933) The nature of the intertidal zonation of plants and animals. J Mar Biol Assoc UK 18:435-476

Crisp DJ (1974) Factors influencing the settlement of marine invertebrate larvae. In: Grant PT, Mackie AM (eds) Chemoreception in marine organisms. Academic Press, London, p 177-245

Cronin TW, Forward RB Jr (1986) Vertical migration cycles of crab larvae and their role in larval dispersal. Bull Mar Sci 39:192-201

Duchêne JC, Queiroga H (2001) Use of an intelligent CCD camera for the study of endogenous vertical migration rhythms in first zoeae of the crab Carcinus maenas. Mar Biol 139:901-909

Eggleston DB, Armstrong DA (1995) Pre- and post-settlement determinants of estuarine Dungeness crab recruitment. Ecol Monogr 65:193-216

Fernandez M, Iribarne O, Armstrong D (1993) Habitat selection by young-of-the-year Dungeness crab, Cancer magister, and predation risk in intertidal habitats. Mar Ecol Prog Ser 92:171-177

Forward RB Jr (1988) Diel vertical migration: zooplankton photobiology and behavior. Oceanogr Mar Biol Annu Rev 26:361-393

Forward RB Jr, Rittschof D (1994) Photoresponses of crab megalopae in offshore and estuarine waters: implications for transport. J Exp Mar Biol Ecol 182:183-192

Forward RB Jr, Tankersley RA (2001) Selective tidal stream transport of marine animals. Oceanogr Mar Biol Annu Rev 39:305-353

Forward RB Jr, Frankel DAZ, Rittschof D (1994) Molting of megalopae from the blue crab Callinectes sapidus: effects of offshore and estuarine cues. Mar Ecol Prog Ser 113: $55-59$

Forward RB Jr, De Vries MC, Rittschof D, Frankel DAZ, Bischoff JP, Fisher CM, Welch JM (1996) Effects of environmental cues on metamorphosis of the blue crab Callinectes sapidus. Mar Ecol Prog Ser 131:165-177

Gosselin LA, Qian PE (1997) Juvenile mortality in benthic marine invertebrates. Mar Ecol Prog Ser 146:265-282

Hedvall O, Moksnes PO, Pihl L (1998) Active habitat selection by megalopae and juvenile shore crabs Carcinus maenas: a laboratory study in an annular flume. Hydrobiologia 375/376:89-100

Herrnkind WF, Butler MJ IV (1986) Factors regulating postlarval settlement and juvenile microhabitat use by spiny lobsters, Panulirus argus. Mar Ecol Prog Ser 34:23-30

Hunt HL, Scheibling RE (1997) Role of early post-settlement mortality in recruitment of benthic marine invertebrates. Mar Ecol Prog Ser 155:269-301

Liu H, Loneragan NR (1997) Size and time of day affect the response of postlarvae and early juvenile grooved tiger prawns Penaeus semisulcatus De Haan (Decapoda: Penaeidae) to natural and artificial seagrass in the laboratory. J Exp Mar Biol Ecol 211:263-277

Meadows PS, Campbell JI (1972) Habitat selection by aquatic invertebrates. Adv Mar Biol 10:271-382

Mohamedeen H, Hartnoll RG (1989) Larval and post-larval growth of individually reared specimens of the common shore crab Carcinus maenas (L.). J Exp Mar Biol Ecol 134: $1-24$ 
Moksnes PO (1999) Recruitment regulation in juvenile shore crabs Carcinus maenas: Importance of intraspecific interactions in space limited refuge habitats. $\mathrm{PhD}$ thesis, Göteborg University

Moksnes PO (2002) The relative importance of habitatspecific settlement, predation and juvenile dispersal for distribution and abundance of young juvenile shore crabs Carcinus maenas L. J Exp Mar Biol Ecol 271:41-73

Moksnes PO, Wennhage H (2001) Methods for estimating decapod larval supply and settlement: importance of larval behavior and development stage. Mar Ecol Prog Ser 209:257-273

Moksnes PO, Lipcius RN, Pihl L, van Montfrans J (1997) Cannibal-prey dynamics in juveniles and postlarvae of the blue crab. J Exp Mar Biol Ecol 215:157-187

Moksnes PO, Pihl L, van Montfrans J (1998) Predation on postlarvae and juveniles of the shore crab Carcinus maenas: importance of shelter, size and cannibalism. Mar Ecol Prog Ser 166:211-225

Morgan SG (1995) Life and death in the plankton: larval mortality and adaptation. In: McEdward L (ed) Biology of marine invertebrate larvae. CRC Press, Boca Raton, FL, p 279-321

Morgan SG (2001) The larval ecology of marine communities. In: Bertness et al. (eds) Marine community ecology. Sinauer Associates, Boca Raton, FL, p 159-181

Nelson TC (1928) Pelagic dissoconchs of the common mussel, Mytilus edulis, with observations on the behaviour of the larvae of allied genera. Biol Bull (Woods Hole) 55: 180-192

Ólafsson EB, Peterson CH, Ambrose WG Jr (1994) Does recruitment limitation structure populations and communities of macro-invertebrates in marine soft sediments: The relative significance of pre- and post-settlement process. Oceanogr Mar Biol Annu Rev 32:65-109

Pawlik JR (1992) Chemical ecology of the settlement of benthic marine invertebrates. Oceanogr Mar Biol Annu Rev 30:273-335

Pechenik JA (1990) Delayed metamorphosis by larvae of benthic marine invertebrates: does it occur? Is there a price to pay? Ophelia 32:63-94

Pihl L (1986) Exposure, vegetation and sediment as primary factors for mobile epibenthic faunal community structure and production in shallow marine soft bottom areas. Neth J Sea Res 20:75-84

Pihl L, Rosenberg R (1984) Food selection and consumption of the shrimp Crangon crangon in some shallow marine areas in western Sweden. Mar Ecol Prog Ser 15:159-168

Queiroga H (1998) Vertical migration and selective tidal stream transport in the megalopa of the crab Carcinus maenas. Hydrobiologia 375/376:137-149

Queiroga H, Costlow JD Jr, Moreira MH (1994) Larval abundance patterns of Carcinus maenas (Decapoda, Brachyura) in Canal de Mira (Ria de Aveiro, Portugal). Mar Ecol Prog Ser 111:63-72

Queiroga H, Costlow JD Jr, Moreira MH (1997) Vertical migration of the crab Carcinus maenas first zoea in an estuary: implications for tidal stream transport. Mar Ecol Prog Ser 149:121-132

Queiroga H, Moksnes PO, Meireles S (2002) Vertical migration behaviour in the larvae of the shore crab, Carcinus maenas (L.), from a microtidal system (Gullmarsfjord, Sweden). Mar Ecol Prog Ser 237:195-207

Editorial responsibility: Otto Kinne (Editor), Oldendorf/Luhe, Germany
Raffaelli D, Hawkins S. (1996) Intertidal ecology. Chapman \& Hall, London

Rumrill SS (1990) Natural mortality of marine invertebrate larvae. Ophelia 32:163-198

Shanks AL (1995) Mechanisms of cross-shelf dispersal of larval invertebrates and fish. In: McEdward L (ed) Biology of marine invertebrate larvae. CRC Press, Boca Raton, FL, p 323-367

Smith KN, Herrnkind WF (1992) Predation on early juvenile spiny lobsters Panulirus argus (Latreille): influence of size and shelter. J Exp Mar Biol Ecol 157:3-18

Söderkvist J (1997) Water exchange in a shallow bay. MSc thesis, Göteborg University

Sokal RR, Rohlf FJ (1981) Biometry. WH Freeman, New York

Sokal RR, Rohlf FJ (1995) Biometry, 3rd edn. WH Freeman, New York

Stevens BG, Kittaka J (1998) Postlarval settling behavior, substrate preference, and time to metamorphosis for red king crab Paralithodes camtschaticus. Mar Ecol Prog Ser 167: 197-206

Svansson A (1984) Hydrography of the Gullmarsfjord. Institute of Hydrographic Research, Göteborg Ser 23:1-21

Tankersley RA, Forward RB Jr (1994) Endogenous swimming rhythms in estuarine crab megalopae: implications for flood-tide transport. Mar Biol 118:415-423

Tankersley RA, McKelvey LM, Forward RB Jr (1995) Responses of estuarine crab megalopae to pressure, salinity and light: implications for flood-tide transport. Mar Biol 122:391-400

Thorson G (1950) Reproductive and larval ecology of marine bottom invertebrates. Biol Rev 25:1-45

Underwood AJ, Keough MJ (2001) Supply-side ecology: the nature and consequences of variation in recruitment of intertidal organisms. In: Bertness et al. (eds) Marine community ecology. Sinauer Associates, Boca Raton, FL, p $183-200$

van Montfrans J, Epifanio CE, Knott DM, Lipcius RN and 7 others (1995) Settlement of blue crab postlarvae in western Atlantic estuaries. Bull Mar Sci 57:834-854

Welch JM, Forward RB Jr (2001) Flood tide transport of blue crab, Callinectes sapidus, postlarvae: behavioral responses to salinity and turbulence. Mar Biol 139:911-918

Welch JM, Forward RB Jr, Howd PA (1999) Behavioral responses of blue crab Callinectes sapidus postlarvae to turbulence: implications for selective tidal stream transport. Mar Ecol Prog Ser 179:135-143

Wolcott DL, De Vries MC (1994) Offshore megalopae of Callinectes sapidus: depth of collection, molt stage and response to estuarine cues. Mar Ecol Prog Ser 109:157-163

Zeng C, Naylor E (1996a) Endogenous tidal rhythms of vertical migration in field collected zoea-1 larvae of the shore crab Carcinus maenas: implications for ebb tide offshore dispersion. Mar Ecol Prog Ser 132:71-82

Zeng C, Naylor E (1996b) Occurrence in coastal waters and endogenous tidal swimming rhythms of late megalopae of the shore crabs Carcinus maenas: implications for onshore recruitment. Mar Ecol Prog Ser 136:69-79

Zeng C, Naylor E (1996c) Heritability of circa-tidal vertical migration rhythms in zoea larvae of the crab Carcinus maenas (L.). J Exp Mar Biol Ecol 202:239-257

Zeng C, Naylor E, Abelló P (1997) Endogenous control of timing of metamorphosis in megalopae of the shore crab Carcinus maenas. Mar Biol 128:299-305

Submitted: June 25, 2002; Accepted: December 17, 2002

Proofs received from author(s): March 6, 2003 